\title{
Barriers to Patient Portal Access and Use: Evidence from the Health Information National Trends Survey
}

\author{
Sherine El-Toukhy, PhD, MA, Alejandra Méndez, MPH, Shavonne Collins, MD, and \\ Eliseo J. Pérez-Stable, MD
}

Background: Patient access to their medical records through patient portals (PPs) facilitates information exchange and provision of quality health care. Understanding factors that characterize patients with limited access to and use of PPs is needed.

Methods: Data were from the 2017-2018 Health Information National Trends Survey 5, Cycles 1 and 2 , a nationally representative survey of $U S$ adults $\geq 18$ years old $(n=6789)$. Weighted multivariate logistic regressions modeled the associations between patient characteristics and access to, facilitators of use, and use of PPs and their functions.

Results: Individuals without (vs with) a regular doctor (adjusted odds ratio [a0R], 0.4; CI, 0.3-0.5) or health insurance (aOR, 0.4 ; CI, 0.2-0.7), those with high school (aOR 0.4; CI, 0.3-0.5) or with vocational/some college (aOR, 0.5; CI, 04.-0.7) education (vs college/postgraduate), or those with limited English proficiency (vs those who speak English very well) (aOR, 0.7 ; CI, 0.5-0.9) were less likely to report accessing their personal medical records. Women (vs men) were more likely to report accessing their medical records (aOR, 1.5; CI, 1.2-1.8). Similar patterns were found for PPs access and facilitators of use. Less consistent associations emerged between patient characteristics and use of PP functionalities.

Conclusions: PP access and use are low. Having a primary care clinician, patient's educational attainment, and being a woman were factors associated with PP access and use, but not race/ethnicity. Once access was achieved, use of PP functionalities was generally uniform across demographic segments. Facilitating PP access and use among all patient populations is warranted. ( $\mathrm{J}$ Am Board Fam Med 2020;33:953-968.)

Keywords: Electronic Health Records, Information Technology, Limited English Proficiency, Logistic Models, Medical Informatics, Patient Portals, Personal Health Records, Primary Health Care, Surveys and Questionnaires, Telemedicine

\section{Introduction}

Patient engagement is a top priority for US health care systems. ${ }^{1}$ The adoption of electronic health

This article was externally peer reviewed.

Submitted 30 October 2019; revised 3 June 2020; accepted 1 July 2020.

From the Division of Intramural Research, National Institute on Minority Health and Health Disparities, National Institutes of Health, Bethesda, MD (SET); Division of Intramural Research, National Heart, Lung, and Blood Institute, National Institutes of Health, Bethesda, MD (SET, AM); School of Medicine, Indiana University, Indianapolis (AM); School of Medicine, Emory University, Atlanta, GA (SC); Division of Intramural Research, National Heart, Lung, and Blood Institute, National Institutes of Health, Bethesda, MD (EJPS); Office of the Director, National Institute on Minority Health and Health Disparities, Bethesda, MD (EJPS).

Funding: This research was supported in part by the Intramural Research Program of the National Institutes of Health; the records (EHRs) is a system-level strategy to involve patients in their health care and increase their ability to make informed decisions. ${ }^{2,3}$ EHRs have

National Institute on Minority Health and Health Disparities; and the National Heart, Lung, and Blood Institute. SET, EJPS, and AM were supported by the Intramural Research Program; National Institute on Minority Health and Health Disparities and the Intramural Research Program; National Heart, Lung, and Blood Institute, National Institutes of Health. SC has been funded by the Medical Research Scholars Program, National Institutes of Health and contributions to the Foundation for the NIH from the Doris Duke Charitable Foundation (DDCF Grant \# 2014194), Genentech, Elsevier, and other private donors.

Conflict of interest: None.

Human subjects statement: This project only involved the use of deidentified data, which is considered "not human subjects research." "Not human subjects research" requires no IRB review or approval per NIH policy and 45 CFR 46. 
tethered patient portals (PPs) where health care providers provide patients around-the-clock access to their health information (cf: personal health records that are patient owned/controlled). ${ }^{4}$ When activated, PPs facilitate the exchange of protected health information electronically between patients and clinicians and allow patients to message their doctor, schedule appointments, and refill medications. ${ }^{5}$ Although use of PPs has been linked to better medication adherence and higher patient satisfaction, 6,7 less is known about patients' use and access of PPs, a key determinant of EHRs wide adoption and impact., ${ }^{2,8}$

Through the 2009 Health Information Technology for Economic and Clinical Health (HITECH) Act, federal policies incentivized the adoption and meaningful use of EHRs to leverage health information technology to improve health care. ${ }^{1,9-11}$ This shift toward a digital ecosystem reflects an emphasis on person-centered care and an overhaul of health care systems to increase efficiency, achieve health equity, and reduce cost. $^{12}$ Indeed, on a systems level, EHRs are associated with improved health care quality and efficiency. ${ }^{13}$ These federal policies resulted in an increase in adoption of basic EHRs from $9.4 \%$ to $83.8 \%$ and of comprehensive EHRs from $1.6 \%$ to $40 \%$ between 2008 and 2015 in nonfederal acute care hospitals. ${ }^{14}$

The Promoting Interoperability Program incentivized health care providers to demonstrate meaningful use of EHRs through progressive demonstration of core objectives. Specifically, eligible professionals and hospitals must give patients the ability to "view online, download, and transmit their health information and hospital admission information" to meet meaningful use objectives for adoption and use of EHRs. ${ }^{15,16}$ However, literature has largely focused on the architecture of EHRs, facilitators of and barriers to adoption by hospitals and clinicians, and privacy and security concerns. ${ }^{8}$ Patient studies have focused on

Author contributions: SET conceptualized the study, ran preliminary analyses, and drafted the manuscript; AM and SC reviewed the literature; SET and EJPS interpreted the data and critically reviewed the manuscript for intellectual content. All authors approved the manuscript as submitted. International Management Systems, Inc., a professional statistical support service, performed the data analysis.

Notes: This study was initiated while AM and SC were affiliated with the National Institutes of Health.

Corresponding author: Sherine El-Toukhy, Stadtman Investigator, Intramural Research Program, National Institute on Minority Health and Health Disparities, National Institutes of Health, 7201 Wisconsin Ave, Room 533M, Bethesda, MD 20814 (E-mail: sherine.el-toukhy@ nih.gov). perceptions of the utility and adoption of $\mathrm{PPs},{ }^{17} \mathrm{PPs}$ access and use in specific settings, ${ }^{18,19}$ and/or among specific patient populations. ${ }^{19-23}$

The dearth of national studies on disparities in patient access and use of PPs exclude patients, an important stakeholder in PPs adoption and impact. ${ }^{24}$ Furthermore, inequitable access to and use of PPs raise concerns for their potential to exacerbate health disparities. ${ }^{2}$ For example, Lin et $\mathrm{al}^{25}$ showed that of $95 \%$ of patients who had access to their electronic information, only $10 \%$ had actually used their information where low rates of access and use of electronic medical information were observed among patients in hospitals located in counties with high proportions of residents eligible for both Medicare and Medicaid, with high proportions of Hispanics, or with low computer ownership and internet access. Among insured individuals who had visited their clinicians in the past year, racial and ethnic groups and individuals on Medicaid were less likely to be offered PPs access. ${ }^{23}$ Indeed, studies identified significant barriers to PPs access and use such as limited Internet access, limited technical skills, potential security breaches and, for limited health literacy individuals, challenges with reading and writing. ${ }^{24,26,27}$ Because many of these barriers are more prevalent among racial and ethnic minority groups and persons of less privileged socioeconomic status, ${ }^{28}$ identifying factors associated with PPs access and use is important. In a national sample of US adults, we examined the extent to which patient characteristics, particularly race/ethnicity and socioeconomic status, were associated with 1) levels of access to and use of PPs and factors facilitating such use, and 2) use of PPs functionalities.

\section{Methods}

Data were from the 2017-2018 Health Information National Trends Survey 5, cycles 1 (H5C1) and 2 ( $\mathrm{H} 5 \mathrm{C} 2) . \mathrm{H} 5 \mathrm{C} 1$ and $\mathrm{H} 5 \mathrm{C} 2$ were nationally representative, self-administered, mail surveys of US adults $\geq 18$ years that evaluated public perceptions and use of PPs. Participants $(n=6789)$ were sampled from a random selection of nonvacant residential addresses stratified by minority concentration (stage 1) and a selection of an adult within the household using Next Birthday Method (stage 2). High minority concentration areas had $\geq 34 \%$ Latinos or Blacks and constituted $63.8 \%$ and $69.4 \%$ of sample addresses in $\mathrm{H} 5 \mathrm{C} 1$ and $\mathrm{H} 5 \mathrm{C} 2$, respectively. All other addresses constituted low minority concentration areas and comprised $36.2 \%$ and 
$31.6 \%$. Census tract level characteristics were based on the 2011 to 2015 American Community Survey (ACS) for H5C1 and 2012 to 2016 ACS for H5C2. Data were collected between $01 / 25$ and $05 / 05 / 2017$ for H5C1 and between 01/26 and 05/02/2018 for H5C2. The overall household response rate was $32.3 \%$ and $32.8 \%$ for $\mathrm{H} 5 \mathrm{C} 1$ and $\mathrm{H} 5 \mathrm{C} 2$. Additional information on the Health Information National Trends Survey can be found online (hints.cancer.gov).

\section{Measures}

Access to PPs was assessed with, "Do any of your doctors/health care providers maintain your medical records in a computerized system?" and "Have you ever been offered online access to your medical records by your health care provider?" [ 1 =yes, $0=$ no/do not know]. Facilitators of using PPs included: "Have your health care provider/ doctors/nurses/office staff ever encouraged you to use an online medical record?" [ $1=$ yes, $0=$ no] and "How confident are you that safeguards are in place to protect your medical records?" [ $1=$ very confident, 0 = somewhat confident/not confident]. Use of PPs was assessed with: "How many times did you access your online medical record in the past 12 months?" and "How many times did you access a family member's online medical record through a secure website/app?" [1=1 or more times and $0=0$ times].

Those who have accessed their PPs at least once in the past year $(n=2151)$ were asked questions about their knowledge and use of PPs functionalities. The stem question for PPs content knowledge was: "Do any of your online medical records include 1) laboratory test results, 2) current list of medications, 3) a list of health/medical problems, 4) an allergy list, 5) summaries of your office visits, 6) clinical notes, and 7) an immunization or vaccination history" $[1=$ yes, $0=$ no/do not know]. The stem question for PPs function use was: "In the past 12 months, have you used your online medical record to 1) make appointments with a health care provider; 2) request refill of medications; 3) fill out forms or paperwork related to your health care; 4) request correction of inaccurate information; 5) securely message health care provider and staff (eg, email); 6) look up test results; 7) monitor your health; 8) download your health information to your computer or mobile device such as a cell phone or tablet; 9) add health information to share with your health care provider such as health concerns, symptoms, and side effects; and 10) help you make a decision about how to treat an illness or condition" [ $1=$ yes, $0=$ no].

Data on gender, age, race/ethnicity, income, education, employment, marital status, place of birth, English language proficiency, having health insurance and a regular provider, and general health were collected. Internet use, means to access the Internet, and mobile device ownership were collected. Census region and rural-urban classification were provided.

\section{Analyses}

Weighted missing percentage for demographic characteristics was highest for income $(9.7 \%)$ and race/ethnicity (8\%). Missingness on all other variables, including outcome variables, was $<4 \%$. Little's test showed that missingness on variables collected at both waves was not completely at ran$\operatorname{dom} \quad\left(\chi^{2}=16505.72 ; \quad d f=14235 ; \quad P<.001\right){ }^{29}$ Outcome variables between participants with observed and missing values differed on key demographic characteristics (data not shown). We imputed data using hot-deck method with a weighted donor selection method ( $\mathrm{n}=20$ donors). ${ }^{30}$ All bivariate comparisons and models were based on imputed data.

Using SAS 9.4 (SAS Institute Inc., Cary, NC), weighted multivariate logistic regression modeled the associations between patient characteristics and PPs access and use. We excluded variables with a correlation of 0.40 or higher to avoid overadjusting for patient characteristics. These variables were income, employment, place of birth, and cellphone ownership, which were correlated with education $(r=0.44)$, age $(r=0.50)$, language proficiency $(r=0.43)$, and smartphone ownership $(r=-0.64)$, respectively, at $P<.0001$ level. All analyses incorporated the final sample weight to calculate population estimates and 100 replicate weights to calculate standard error of estimates using jackknife replication method.

\section{Results}

Sample characteristics are listed in Table 1.

\section{Associations between Patient Characteristics and PPs Access and Use}

Roughly 3 quarters of participants (76.9\%) reported their provider maintained electronic medical records 
Table 1. Weighted Sample Characteristics of 6789 Participants in the 2017-2018 Health Information National Trends Survey 5, Cycles 1 and 2, US

\begin{tabular}{|c|c|c|c|c|}
\hline & $n$ & \% Weighted & LL & UL \\
\hline \multicolumn{5}{|l|}{ Gender } \\
\hline Men & 2759 & 48.9 & 48.7 & 49.1 \\
\hline Women & 4030 & 51.1 & 50.9 & 51.3 \\
\hline \multicolumn{5}{|l|}{ Age, years } \\
\hline 18 to 39 & 1248 & 30.6 & 28.7 & 32.4 \\
\hline 40 to 59 & 2391 & 42.3 & 40.5 & 44.1 \\
\hline$\geq 60$ & 3150 & 27.1 & 26.9 & 27.4 \\
\hline \multicolumn{5}{|l|}{ Race/ethnicity } \\
\hline Latino & 995 & 15.8 & 15.5 & 16.2 \\
\hline White & 4297 & 65.2 & 64.7 & 65.7 \\
\hline Black & 923 & 10.5 & 10.0 & 11.0 \\
\hline Other* & 574 & 8.4 & 8.2 & 8.7 \\
\hline \multicolumn{5}{|l|}{ Annual household income } \\
\hline$<\$ 20,000$ & 1254 & 17.3 & 15.9 & 18.8 \\
\hline$\$ 20,000$ to $\$ 49,999$ & 1829 & 26.1 & 24.5 & 27.7 \\
\hline$\$ 50,000$ to $\$ 74,999$ & 1237 & 18.5 & 17.0 & 20.0 \\
\hline$\geq \$ 75000$ & 2470 & 38.1 & 36.2 & 39.9 \\
\hline \multicolumn{5}{|l|}{ Education } \\
\hline$<$ High school & 504 & 8.8 & 7.6 & 10.0 \\
\hline High school graduate & 1279 & 22.6 & 21.4 & 23.8 \\
\hline Vocational school, some college & 2040 & 36.4 & 35.3 & 37.6 \\
\hline College graduate, postgraduate & 2967 & 32.2 & 31.9 & 32.4 \\
\hline \multicolumn{5}{|l|}{ Employment } \\
\hline Employed & 3423 & 57.9 & 55.8 & 59.9 \\
\hline Unemployed & 3366 & 42.1 & 40.1 & 44.2 \\
\hline \multicolumn{5}{|l|}{ Marital status } \\
\hline Single & 1169 & 30.2 & 30.0 & 30.5 \\
\hline Married, living as married & 3595 & 53.9 & 53.1 & 54.7 \\
\hline Separated, widowed & 2024 & 15.9 & 15.1 & 16.6 \\
\hline \multicolumn{5}{|l|}{ Place of birth } \\
\hline United States & 5826 & 85.5 & 84.4 & 86.5 \\
\hline Foreign born & 963 & 14.5 & 13.5 & 15.6 \\
\hline \multicolumn{5}{|l|}{ Speak English } \\
\hline Very well & 6042 & 88.3 & 87.2 & 89.3 \\
\hline Well, not well, not at all & 747 & 11.7 & 10.7 & 12.8 \\
\hline \multicolumn{5}{|l|}{ Regular provider } \\
\hline Yes & 4848 & 65.4 & 63.6 & 67.3 \\
\hline No & 1941 & 34.6 & 32.7 & 36.4 \\
\hline \multicolumn{5}{|l|}{ Health insurance } \\
\hline Yes & 6441 & 91.6 & 91.5 & 91.7 \\
\hline No & 348 & 8.4 & 8.3 & 8.5 \\
\hline \multicolumn{5}{|l|}{ General health } \\
\hline Excellent/good & 5638 & 84.1 & 82.6 & 85.6 \\
\hline Fair/poor & 1151 & 15.9 & 14.4 & 17.4 \\
\hline \multicolumn{5}{|l|}{ Census region } \\
\hline Northeast census region & 1065 & 17.9 & 17.9 & 17.9 \\
\hline Midwest census region & 1249 & 21.0 & 21.0 & 21.0 \\
\hline South census region & 2893 & 37.6 & 37.6 & 37.6 \\
\hline
\end{tabular}




\begin{tabular}{lrrrr}
\hline & $n$ & \% Weighted & LL & UL \\
\hline West census region & 1582 & 23.5 & 23.5 & \\
Rural/urban designation & & & & \\
Metro & 5863 & 86.1 & 84.8 & \\
Urban & 834 & 12.4 & 11.2 & 13.7 \\
Rural & 92 & 1.5 & 1.0 & 2.0 \\
\hline
\end{tabular}

LL, lower limit; UL, upper limit.

$\mathrm{n}=6789$; Imputed subjects have 20 records, thus imputed $n$ is $1 / 20$ th of a subject rounded to the nearest integer.

*Asians, Pacific Islanders, and multiple races.

but only $47.2 \%$ reported being offered access to them, $39.2 \%$ reported their provider encouraged their use, $27.2 \%$ were confident electronic medical records were safe, and $29.3 \%$ and $9.3 \%$ reported accessing their own or their families' medical records in the past year.

Gender, education, marital status, and having a regular clinician were factors associated with access, facilitators of use, and use of PPs (Table 2). Age, language proficiency, and having health insurance were also associated with PPs access and use but not race and ethnicity. We highlight some findings and refer the reader to the tables for a complete overview of significant associations.

\section{Access}

Women (vs men) were more likely to report providers offered them access to electronic records (48.4\% vs $36.5 \%$; adjusted odds ratio [aOR], 1.7). Compared with those with college education or higher $(58.9 \%)$, persons with less than high school education $(27.9 \%$; aOR, 0.4$)$, high school graduates (37.8\%; aOR, 0.6), and persons with vocational/ some college degree (40.4\%; aOR, 0.6) were less likely to report their providers offered them access to electronic records. Patients without (vs with) a regular clinician $(31.6 \%$ vs $49.2 \%$; aOR, 0.3$)$ or health insurance $(17.7 \%$ vs $45.0 \%$; aOR, 0.5$)$ were less likely to report their providers offered them access to electronic records.

\section{Facilitators of Use}

Women (vs men) were more likely to report providers encouraged use of electronic records (39.4\% vs $29.5 \%$; aOR, 1.6). Compared with those with college education or higher (49.1\%), high school graduates $(31.2 \%$; aOR, 0.4$)$ and persons with vocational/some college degree $(31.1 \%$; aOR, 0.6$)$ were less likely to report their providers encouraged use of electronic records. Patients without (vs with) a regular clinician were less likely to report their providers encouraged their use $(20.0 \%$ vs $43.2 \%$; aOR, $0.5)$. Individuals without (vs with) a regular doctor (22.9\% vs $28.0 \%$; aOR, 0.7 ) or who reported fair or poor (vs excellent/good) health $(22.3 \%$ vs $27.1 \%$; aOR, 0.7) had less confidence in the safety of electronic records.

\section{Use}

Women (vs men) were more likely to report past year access to their own electronic records $(30.2 \%$ vs $23.0 \%$; aOR, 1.5). Compared with those with college education or higher, high school graduates were less likely to report that they accessed their personal $(44.2 \%$ vs $17.8 \%$; aOR, 0.4$)$ or family's $(15.5 \%$ vs $3.8 \%$; aOR, 0.3$)$ electronic records. Similarly, individuals with vocational/some college education were less likely to report that they access their personal ( $44.2 \%$ vs $25.7 \%$; aOR, 0.5 ) or their family's (15.5\% vs 7.8\%; aOR, 0.5) electronic records. Patients without (vs with) a regular clinician were less likely to report that they accessed their personal $(17.7 \%$ vs $32.0 \%$; aOR, 0.4$)$ or family's (5.4\% vs $10.8 \%$; aOR, 0.6 ) electronic records. Individuals with limited English proficiency $(20.9 \%$ vs $27.8 \%$; aOR, 0.7$)$ or those without health insurance $(11.9 \%$ vs $28.1 \%$; aOR, 0.4$)$ were less likely to report having accessed their personal records in the past year compared with those who speak English very well and those with health insurance.

Although 82\% $(n=5280 ; 95 \%$ CI, 80.6-83.3) reported having internet access and any mobile device ownership was at $98 \%(\mathrm{n}=6656 ; 95 \% \mathrm{CI}$, 97.5-98.4), notable differences still exist in internet access and mobile device ownership especially by age, race and ethnicity, education, and language 
Table 2. Multivariate Logistic Regression Models of Associations between Patient Characteristics and Patient Portals Access and Use in the Health Information National Trends Survey 5, Cycles 1 and 2, US

\begin{tabular}{|c|c|c|c|c|c|c|}
\hline & \multicolumn{2}{|c|}{ Access } & \multicolumn{2}{|c|}{ Facilitators of Use } & \multicolumn{2}{|c|}{ Use Behavior } \\
\hline & $\begin{array}{l}\text { Provider } \\
\text { Maintains } \\
\text { Medical Records, } \\
\text { aOR }(95 \% \text { CI })\end{array}$ & $\begin{array}{l}\text { Provider Offers } \\
\text { Medical Records } \\
\text { Access, aOR (95\% } \\
\text { CI) }\end{array}$ & $\begin{array}{c}\text { Provider } \\
\text { Encourages Medical } \\
\text { Record Use }{ }^{\dagger}, \text { aOR } \\
(95 \% \mathrm{CI})\end{array}$ & $\begin{array}{c}\text { Confident } \\
\text { Medical } \\
\text { Records Safe, } \\
\text { aOR (95\% CI) }\end{array}$ & $\begin{array}{l}\text { Access Own } \\
\text { Medical } \\
\text { Record, aOR } \\
(95 \% \mathrm{CI})\end{array}$ & $\begin{array}{l}\text { Access Family } \\
\text { Medical } \\
\text { Record }^{\dagger}, \text { aOR } \\
(95 \% \mathrm{CI})\end{array}$ \\
\hline \multicolumn{7}{|l|}{$\begin{array}{l}\text { Gender (ref: } \\
\text { men) }\end{array}$} \\
\hline Women & $1.7(1.4-2.0)$ & $1.7(1.5-2.0)$ & $1.6(1.3-2.0)$ & $1.2(0.9-1.4)$ & $1.5(1.2-1.8)$ & $1.6(1.0-2.3)$ \\
\hline \multicolumn{7}{|l|}{$\begin{array}{c}\text { Age (ref: } 18 \text { to } \\
39 \text { years) }\end{array}$} \\
\hline 40 to 59 years & $1.2(0.9-1.6)$ & $0.9(0.8-1.2)$ & $0.9(0.7-1.3)$ & $0.9(0.7-1.1)$ & $1.1(0.9-1.4)$ & $0.9(0.6-1.3)$ \\
\hline$\geq 60$ years & $1.4(1.0-1.8)$ & $0.8(0.7-1.0)$ & $0.8(0.6-1.0)$ & $1.0(0.8-1.3)$ & $0.8(0.6-0.9)$ & $0.7(0.4-1.2)$ \\
\hline \multicolumn{7}{|l|}{$\begin{array}{r}\text { Race/ethnicity } \\
\text { (ref: White) }\end{array}$} \\
\hline Latino & $1.2(0.9-1.5)$ & $0.9(0.7-1.1)$ & $0.8(0.6-1.2)$ & $1.3(0.9-1.8)$ & $0.9(0.7-1.2)$ & $1.1(0.7-1.8)$ \\
\hline Black & $1.2(0.8-1.7)$ & $0.8(0.7-1.0)$ & $1.0(0.8-1.5)$ & $1.0(0.8-1.4)$ & $0.9(0.7-1.2)$ & $0.8(0.4-1.6)$ \\
\hline Other* & $0.9(0.5-1.4)$ & $0.8(0.6-1.0)$ & $0.8(0.6-1.2)$ & $0.9(0.7-1.3)$ & $1.2(0.9-1.7)$ & $1.2(0.7-2.1)$ \\
\hline \multicolumn{7}{|l|}{$\begin{array}{l}\text { Education (ref: } \\
\text { college/post } \\
\text { grad) }\end{array}$} \\
\hline$<$ High school & $0.5(0.3-0.8)$ & $0.4(0.3-0.7)$ & $0.5(0.2-1.0)$ & $1.4(0.9-2.1)$ & $0.3(0.2-0.5)$ & $0.7(0.3-1.7)$ \\
\hline $\begin{array}{l}\text { High school } \\
\text { grad }\end{array}$ & $0.6(0.4-0.7)$ & $0.6(0.4-0.7)$ & $0.4(0.3-0.6)$ & $1.0(0.8-1.4)$ & $0.4(0.3-0.5)$ & $0.3(0.1-0.5)$ \\
\hline $\begin{array}{l}\text { Vocational, } \\
\text { some college }\end{array}$ & $0.6(0.5-0.8)$ & $0.6(0.5-0.8)$ & $0.6(0.5-0.8)$ & $1.2(0.9-1.5)$ & $0.5(0.4-0.7)$ & $0.5(0.4-0.8)$ \\
\hline \multicolumn{7}{|l|}{$\begin{array}{l}\text { Marital status } \\
\text { (ref: married, } \\
\text { living as } \\
\text { married) }\end{array}$} \\
\hline Single & $0.6(0.4-0.8)$ & $0.5(0.4-0.6)$ & $0.4(0.3-0.6)$ & $1.0(0.8-1.3)$ & $0.6(0.5-0.8)$ & $0.2(0.1-0.6)$ \\
\hline $\begin{array}{l}\text { Separated, } \\
\text { widowed }\end{array}$ & $0.7(0.5-0.9)$ & $0.6(0.5-0.7)$ & $0.6(0.5-0.8)$ & $1.0(0.9-1.3)$ & $0.6(0.5-0.7)$ & $0.4(0.2-0.8)$ \\
\hline \multicolumn{7}{|l|}{$\begin{array}{l}\text { Speak English } \\
\text { (ref: very } \\
\text { well) }\end{array}$} \\
\hline $\begin{array}{l}\text { Well, not } \\
\text { well, not at } \\
\text { all }\end{array}$ & $0.7(0.5-0.9)$ & $0.6(0.4-0.8)$ & $0.8(0.5-1.2)$ & $0.8(0.6-1.1)$ & $0.7(0.5-0.9)$ & $1.2(0.7-2.2)$ \\
\hline \multicolumn{7}{|l|}{$\begin{array}{l}\text { Health } \\
\text { insurance } \\
\text { (ref: yes) }\end{array}$} \\
\hline No & $0.5(0.3-0.9)$ & $0.5(0.3-0.8)$ & $0.7(0.3-1.5)$ & $0.9(0.5-1.4)$ & $0.4(0.2-0.7)$ & $0.8(0.3-2.3)$ \\
\hline \multicolumn{7}{|l|}{$\begin{array}{l}\text { Regular } \\
\text { provider (ref: } \\
\text { yes) }\end{array}$} \\
\hline No & $0.3(0.2-0.4)$ & $0.4(0.4-0.5)$ & $0.5(0.4-0.6)$ & $0.7(0.6-0.9)$ & $0.4(0.3-0.5)$ & $0.6(0.4-0.9)$ \\
\hline \multicolumn{7}{|l|}{$\begin{array}{l}\text { General health } \\
\text { (ref: } \\
\text { excellent/ } \\
\text { good) }\end{array}$} \\
\hline Fair/poor & $0.9(0.7-1.1)$ & $0.9(0.8-1.2)$ & $1.0(0.8-1.4)$ & $0.7(0.5-0.9)$ & $0.9(0.7-1.1)$ & $1.0(0.6-1.6)$ \\
\hline \multicolumn{7}{|l|}{$\begin{array}{l}\text { Census region } \\
\text { (ref: } \\
\text { Northeast) }\end{array}$} \\
\hline Midwest & $0.8(0.6-1.2)$ & $0.9(0.7-1.3)$ & $1.0(0.7-1.7)$ & $1.2(0.9-1.6)$ & $1.2(0.9-1.7)$ & $1.1(0.6-2.1)$ \\
\hline South & $0.7(0.5-0.9)$ & $0.8(0.6-1.0)$ & $0.9(0.7-1.5)$ & $1.1(0.9-1.4)$ & $1.0(0.8-1.4)$ & $1.2(0.7-2.1)$ \\
\hline
\end{tabular}




\begin{tabular}{|c|c|c|c|c|c|c|}
\hline & \multicolumn{2}{|c|}{ Access } & \multicolumn{2}{|c|}{ Facilitators of Use } & \multicolumn{2}{|c|}{ Use Behavior } \\
\hline & $\begin{array}{l}\text { Provider } \\
\text { Maintains } \\
\text { Medical Records, } \\
\text { aOR }(95 \% \text { CI })\end{array}$ & $\begin{array}{c}\text { Provider Offers } \\
\text { Medical Records } \\
\text { Access, aOR (95\% } \\
\text { CI) }\end{array}$ & $\begin{array}{c}\text { Provider } \\
\text { Encourages Medical } \\
\text { Record Use }^{\dagger}, \text { aOR } \\
(95 \% \mathrm{CI})\end{array}$ & $\begin{array}{c}\text { Confident } \\
\text { Medical } \\
\text { Records Safe, } \\
\text { aOR (95\% CI) }\end{array}$ & $\begin{array}{l}\text { Access Own } \\
\text { Medical } \\
\text { Record, aOR } \\
(95 \% \mathrm{CI})\end{array}$ & $\begin{array}{l}\text { Access Family } \\
\text { Medical } \\
\text { Record }^{\dagger}, \text { aOR } \\
(95 \% \text { CI })\end{array}$ \\
\hline West & $0.8(0.6-1.1)$ & $0.9(0.6-1.1)$ & $1.1(0.8-1.7)$ & $0.9(0.7-1.2)$ & $1.3(0.9-1.7)$ & $1.5(0.9-2.6)$ \\
\hline \multicolumn{7}{|c|}{$\begin{array}{l}\text { Rural/urban } \\
\text { designation } \\
\text { (ref: metro) }\end{array}$} \\
\hline Urban & $1.0(0.7-1.5)$ & $0.7(0.5-0.9)$ & $0.6(0.4-0.9)$ & $1.0(0.8-1.4)$ & $0.6(0.4-0.8)$ & $0.9(0.5-1.9)$ \\
\hline Rural & $0.7(0.3-1.5)$ & $0.6(0.3-1.2)$ & $0.6(0.2-1.6)$ & $0.9(0.4-2.1)$ & $0.7(0.4-1.4)$ & $0.5(0.01-30.3)$ \\
\hline
\end{tabular}

aOR, adjusted odds ratio; CI, confidence interval.

$\mathrm{n}=6789$.

*Asians, Pacific Islanders, and multiple races.

${ }^{\dagger}$ Question was omitted in 2018 H5C2, so $\mathrm{n}=3285$ based on H5C1 only.

Bolded cells are statistically meaningful.

Participants in $\mathrm{H} 5 \mathrm{C} 2$ were asked the number of times that they accessed their own medical records only if they responded "yes" to whether they have been offered online access to medical records. Participants then reported who offered them access (i.e., healthcare provider, health insurer, someone else). To harmonize the data, we coded participants who said "no/don't know" to "have you been offered online access to your medical records?" as "no" and those who selected "healthcare provider" to "who offered you online access to your medical records?" as "yes."

Logistic regression analysis modeled the probability of 1 (eg, provider maintained electronic medical records, provider offered access to electronic medical records).

proficiency (data not shown). Therefore, we added these factors to the models for accessing personal and family electronic records (Appendix Table 1). We found that internet access and device ownership were independently associated with accessing personal electronic records in the past year. Individuals not having (vs having) broadband (31.2\% vs $37.7 \%$; aOR, 0.7$)$ or Wi-Fi $(24.3 \%$ vs $37.2 \%$; aOR, 0.7 ) access or not owning (vs owning) a tablet $(15.2 \%$ vs $37.6 \%$; aOR, 0.6$)$ or a smartphone $(11.0 \%$ vs $33.5 \%$; aOR, 0.5$)$ were less likely to report accessing their personal records.

\section{Associations between Patient Characteristics and Use of PP Functionalities}

Knowledge of PP functions varied, with laboratory test results (91.5\%) being the most known function and clinical notes $(50.6 \%)$ being the least (Figure 1). Use of PP functions varied, with viewing test results $(84.3 \%)$ being the most used function and requesting corrections (7.1\%) being the least. All other functions were reportedly used by $50 \%$ or less of participants.

Few patient characteristics were associated with PP functions use (Table 3). Individuals aged $\geq 60$ years (vs 18 to 39 years old) were more likely to use PPs to refill medications ( $41.2 \%$ vs $40.3 \%$; aOR, 1.7) but less likely to message their health care provider $(45.4 \%$ vs $54.6 \%$; aOR, 0.7$)$, make decisions ( $14.5 \%$ vs $32.1 \%$; aOR, 0.5 ), or download health information (18.2\% vs $17.2 \%$; aOR, 0.6). Compared with college/postgraduates (42.7\%), individuals with vocational/some college education (36.5\%; aOR, 0.7), high school graduates (39.1\%; $\mathrm{aOR}, 0.6)$, and those with less than high school education (23.3\%; aOR, 0.3) were less likely to report using PPs to complete forms. Persons with less than high school education (vs college and postgraduates) were also less likely to use PPs to make decisions $(17.0 \%$ vs $24.6 \%$; aOR, 0.4$)$ or download information (20.3\% vs $22.6 \%$; aOR, 0.3 ). Individuals who do not have (vs have) a regular provider were less likely to report using PPs to message health care provider (39.6\% vs $49.5 \%$; aOR, 0.7 ). Reported use of PPs to refill medications was less likely among individuals with limited English proficiency (37.6\% vs $39.4 \%$; aOR, 0.5 ) but more likely among those with fair or poor health $(53.0 \%$ vs $37.2 \%$; aOR, 1.6) compared with those who are language proficient and those with excellent/good health.

West census region (vs Northeast) residents were more likely to report using PPs to view test results $(88.1 \%$ vs $70.5 \%$; aOR, 2.8$)$, message their 
Figure 1. Knowledge of patient portals content among 2151 participants in the 2017-2018 Health Information National Trends Survey 5, Cycles 1 and 2, US.

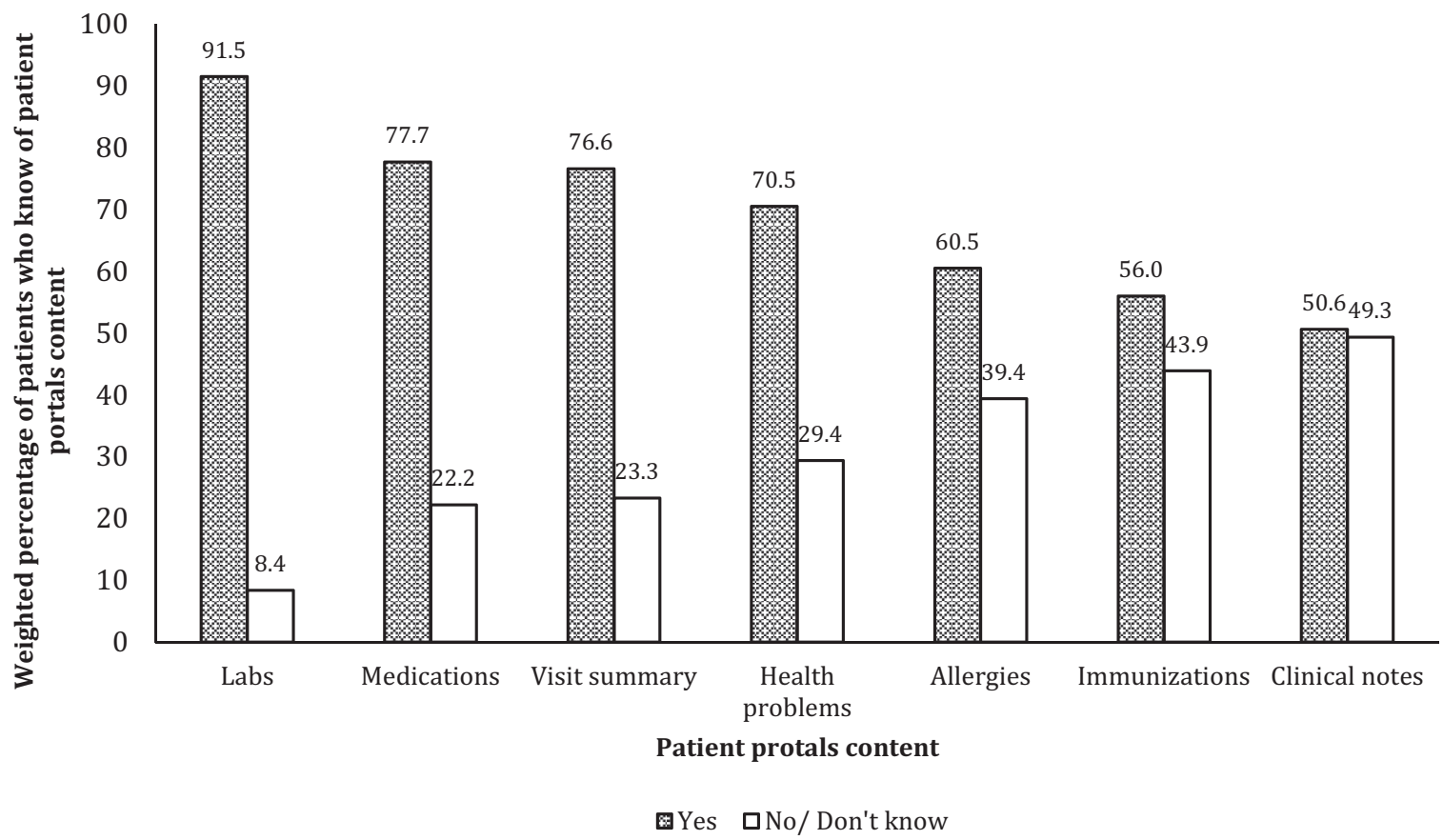

$N=2,151$ (those who accessed their own medical records one or more times in the past 12 months)

For labs and medications, results are based on H5C1 only $(n=1,033)$

provider $(59.5 \%$ vs $37.7 \%$; aOR, 2.5$)$, make appointments (52.4\% vs $26.2 \%$; aOR, 3.5 ), and add information ( $30.5 \%$ vs $14.1 \%$; aOR, 2.4$)$.

\section{Discussion}

This analysis of a nationally representative US sample showed low levels of PPs access and use and identified disparities in access and use by patient's educational level but not by race and ethnic minority status. Furthermore, respondents with a primary care clinician were more likely to report PPs access and use. Concerns about the security of electronic medical data were magnified among persons without a regular clinician and those who reported fair or poor health. Given the health benefits of having a regular primary care clinician ${ }^{31-34}$ and improved health outcomes of PPs use, ${ }^{6,7}$ identifying ways to address low levels of access to and use of PPs in general and disparities by socioeconomic factors and race/ethnicity in specific should be a priority of medical systems. Assuring that all patients, regardless of system or setting, have an identified "regular" clinician who coordinates comprehensive primary care is one step to address PPs access and use disparities and attenuate concerns about data security.

Rates of PP use are low. Consistent with previous research, ${ }^{25}$ under a half reported that they were offered access to their electronic records, with only a third reported accessing their own medical data. This suggests that access does not necessarily translate to use. Policy initiatives could promote the accessibility and use of electronic medical data to patient populations especially in resource-constrained health care settings. One such initiative is raising the thresholds for demonstrating meaningful use under the Centers for Medicare and Medicaid Services' Promoting Interoperability Program. Current levels are set to at least 1 unique patient, ${ }^{35}$ primarily to accommodate concerns from professionals and hospitals around patient-related factors that are beyond their control (eg, Internet access). Raising these thresholds could promote structural changes (eg, improved portals usability) to improve patient access and use of electronic medical data above and beyond individual-level factors. ${ }^{25,36}$

Having a regular health care provider was the only factor consistently associated with PP access, 
Table 3. Multivariate Logistic Regression Models of Associations between Patient Characteristics and Use of Patient Portals Functionalities in the 2017-2018 Health Information National Trends Survey 5, Cycles 1 and 2, US

\begin{tabular}{|c|c|c|c|c|c|}
\hline & $\begin{array}{l}\text { View Results, } \uparrow \\
\text { aOR }(95 \% \text { CI) }\end{array}$ & $\begin{array}{l}\text { Message Healthcare } \\
\text { Provider, aOR } \\
\text { (95\% CI) }\end{array}$ & $\begin{array}{l}\text { Make Appointment, } \dagger \\
\text { aOR }(95 \% \text { CI })\end{array}$ & $\begin{array}{l}\text { Refill Medication, } \\
\text { aOR }(95 \% \mathrm{CI})\end{array}$ & $\begin{array}{c}\text { Complete Forms, } \\
\text { aOR }(95 \% \mathrm{CI})\end{array}$ \\
\hline \multicolumn{6}{|l|}{ Gender (ref: men) } \\
\hline Women & $1.1(0.6-2.0)$ & $0.9(0.7-1.2)$ & $0.8(0.5-1.2)$ & $0.9(0.7-1.2)$ & $1.0(0.8-1.4)$ \\
\hline \multicolumn{6}{|l|}{$\begin{array}{c}\text { Age (ref: } 18 \text { to } \\
39 \text { years) }\end{array}$} \\
\hline 40 to 59 years & $1.3(0.7-2.3)$ & $0.8(0.5-1.1)$ & $0.9(0.5-1.5)$ & $1.1(0.7-1.7)$ & $1.0(0.7-1.6)$ \\
\hline$\geq 60$ years & $0.7(0.4-1.4)$ & $0.7(0.5-0.9)$ & $0.8(0.4-1.3)$ & $1.7(1.1-2.5)$ & $0.8(0.5-1.0)$ \\
\hline \multicolumn{6}{|l|}{$\begin{array}{l}\text { Race/ethnicity (ref: } \\
\text { White) }\end{array}$} \\
\hline Latino & $0.5(0.3-1.0)$ & $0.8(0.5-1.2)$ & $1.0(0.5-2.1)$ & $0.9(0.7-1.4)$ & $0.9(0.6-1.5)$ \\
\hline Black & $0.8(0.4-1.8)$ & $1.0(0.7-1.6)$ & $1.6(0.8-3.0)$ & $1.0(0.7-1.7)$ & $0.7(0.4-1.0)$ \\
\hline Other* & $0.8(0.3-1.9)$ & $0.7(0.4-1.3)$ & $1.5(0.8-2.5)$ & $1.2(0.7-1.9)$ & $0.7(0.4-1.0)$ \\
\hline \multicolumn{6}{|l|}{$\begin{array}{l}\text { Education (ref: } \\
\text { college/post grad) }\end{array}$} \\
\hline$<$ High school & $1.7(0.4-6.5)$ & $1.0(0.3-2.9)$ & $0.2(0.04-1.0)$ & $1.7(0.6-5.0)$ & $0.3(0.1-0.9)$ \\
\hline High school grad & $0.9(0.3-2.7)$ & $1.0(0.7-1.5)$ & $1.1(0.6-2.1)$ & $0.9(0.7-1.4)$ & $0.6(0.4-0.8)$ \\
\hline $\begin{array}{l}\text { Vocational, some } \\
\text { college }\end{array}$ & $1.1(0.6-2.1)$ & $1.0(0.8-1.4)$ & $0.9(0.6-1.4)$ & $1.0(0.7-1.4)$ & $0.7(0.5-0.9)$ \\
\hline \multicolumn{6}{|l|}{$\begin{array}{l}\text { Marital status (ref: } \\
\text { married, living as } \\
\text { married) }\end{array}$} \\
\hline Single & $0.8(0.4-1.7)$ & $1.3(0.9-2.0)$ & $1.4(0.8-2.5)$ & $1.3(0.9-1.9)$ & $1.3(0.9-1.9)$ \\
\hline Separated, widowed & $0.9(0.4-1.8)$ & $0.9(0.6-1.3)$ & $0.9(0.6-1.6)$ & $0.9(0.7-1.3)$ & $0.9(0.7-1.3)$ \\
\hline \multicolumn{6}{|l|}{$\begin{array}{l}\text { Speak English (ref: } \\
\text { very well) }\end{array}$} \\
\hline $\begin{array}{l}\text { Well, not well, not } \\
\text { at all }\end{array}$ & $0.8(0.3-1.8)$ & $0.8(0.4-1.3)$ & $1.4(0.6-3.3)$ & $0.5(0.3-0.9)$ & $0.7(0.3-1.3)$ \\
\hline \multicolumn{6}{|l|}{$\begin{array}{l}\text { Health insurance (ref: } \\
\text { yes) }\end{array}$} \\
\hline No & $0.6(0.1-5.7)$ & $0.9(0.4-2.5)$ & $0.9(0.2-4.5)$ & $0.6(0.2-1.9)$ & $0.6(0.1-2.2)$ \\
\hline \multicolumn{6}{|l|}{$\begin{array}{l}\text { Regular provider (ref: } \\
\text { yes) }\end{array}$} \\
\hline No & $0.8(0.4-1.6)$ & $0.7(0.5-0.9)$ & $1.0(0.6-1.9)$ & $0.8(0.5-1.2)$ & $0.8(0.6-1.1)$ \\
\hline \multicolumn{6}{|l|}{$\begin{array}{l}\text { General health (ref: } \\
\text { excellent/good) }\end{array}$} \\
\hline Fair/poor & $1.1(0.5-2.7)$ & $1.3(0.8-1.9)$ & $1.1(0.7-1.9)$ & $1.6(1.1-2.3)$ & $1.4(0.9-2.1)$ \\
\hline \multicolumn{6}{|l|}{$\begin{array}{l}\text { Census region (ref: } \\
\text { Northeast) }\end{array}$} \\
\hline Midwest & $0.7(0.3-1.7)$ & $1.0(0.7-1.6)$ & $0.9(0.5-1.8)$ & $0.7(0.5-1.1)$ & $1.2(0.7-2.1)$ \\
\hline South & $1.2(0.6-2.3)$ & $1.0(0.8-1.5)$ & $1.5(0.8-2.9)$ & $0.9(0.7-1.4)$ & $1.8(1.2-2.7)$ \\
\hline West & $2.8(1.3-6.3)$ & $2.5(1.7-3.9)$ & $3.5(1.8-6.8)$ & $1.5(0.9-2.2)$ & $1.6(1.0-2.5)$ \\
\hline \multicolumn{6}{|l|}{$\begin{array}{l}\text { Rural/urban } \\
\text { designation (ref: } \\
\text { metro) }\end{array}$} \\
\hline Urban & $1.0(0.4-2.6)$ & $0.9(0.6-1.7)$ & $1.3(0.7-2.5)$ & $1.0(0.7-1.6)$ & $0.7(0.4-1.2)$ \\
\hline Rural & $1.9(0.1-54.8)$ & $0.8(0.3-2.6)$ & $2.4(0.5-12.4)$ & $1.8(0.5-6.4)$ & $1.4(0.4-4.6)$ \\
\hline
\end{tabular}




\begin{tabular}{|c|c|c|c|c|c|}
\hline & $\begin{array}{c}\begin{array}{c}\text { Monitor } \\
\text { health }^{\dagger}\end{array} \\
\text { aOR }(95 \% \text { CI })\end{array}$ & $\begin{array}{l}\text { Make decisions } \\
\text { aOR }(95 \% \mathrm{CI})\end{array}$ & $\begin{array}{c}\text { Add } \\
\text { information } \\
\text { aOR }(95 \% \mathrm{CI})\end{array}$ & $\begin{array}{c}\text { Download } \\
\text { information } \\
\text { aOR }(95 \% \mathrm{CI})\end{array}$ & $\begin{array}{c}\text { Request } \\
\text { correction } \\
\text { aOR }(95 \% \mathrm{CI})\end{array}$ \\
\hline \multicolumn{6}{|l|}{ Gender (ref: men) } \\
\hline Women & $0.7(0.5-1.1)$ & $0.8(0.6-1.2)$ & $1.0(0.8-1.4)$ & $0.8(0.5-1.1)$ & $1.4(0.8-2.3)$ \\
\hline \multicolumn{6}{|l|}{ Age (ref: 18 to 39 years) } \\
\hline 40 to 59 years & $0.9(0.6-1.7)$ & $0.7(0.5-1.0)$ & $1.1(0.8-1.7)$ & $0.8(0.5-1.0)$ & $0.8(0.4-1.6)$ \\
\hline$\geq 60$ years & $0.7(0.4-1.2)$ & $0.5(0.3-0.8)$ & $0.9(0.6-1.4)$ & $0.6(0.4-0.9)$ & $0.7(0.3-1.7)$ \\
\hline \multicolumn{6}{|l|}{ Race/ethnicity (ref: White) } \\
\hline Latino & $0.9(0.4-2.1)$ & $1.0(0.6-1.8)$ & $1.0(0.7-1.8)$ & $1.0(0.7-1.7)$ & $1.2(0.6-2.6)$ \\
\hline Black & $1.6(0.8-3.2)$ & $1.7(1.0-2.9)$ & $1.0(0.7-1.8)$ & $1.1(0.7-1.9)$ & $1.6(0.8-3.0)$ \\
\hline Other $^{*}$ & $1.2(0.6-2.4)$ & $1.0(0.6-1.9)$ & $0.7(0.4-1.4)$ & $0.9(0.6-1.7)$ & $0.9(0.4-2.1)$ \\
\hline \multicolumn{6}{|c|}{ Education (ref: college/post grad) } \\
\hline$<$ High school & $0.7(0.1-4.4)$ & $0.4(0.2-0.9)$ & $0.5(0.2-1.2)$ & $0.3(0.1-0.8)$ & $1.2(0.3-4.6)$ \\
\hline High school grad & $0.9(0.4-1.7)$ & $0.9(0.5-1.5)$ & $0.9(0.6-1.5)$ & $0.5(0.2-1.0)$ & $0.6(0.3-1.5)$ \\
\hline Vocational, some college & $0.8(0.5-1.2)$ & $0.8(0.6-1.2)$ & $0.8(0.6-1.2)$ & $0.9(0.6-1.3)$ & $0.9(0.6-1.6)$ \\
\hline \multicolumn{6}{|c|}{ Marital status (ref: married, living as married) } \\
\hline Single & $0.9(0.5-1.8)$ & $0.9(0.6-1.4)$ & $1.5(0.9-2.2)$ & $0.9(0.5-1.6)$ & $1.2(0.6-2.4)$ \\
\hline Separated, widowed & $0.7(0.4-1.3)$ & $0.8(0.5-1.2)$ & $0.9(0.7-1.3)$ & $1.3(0.8-1.9)$ & $1.6(0.8-3.2)$ \\
\hline \multicolumn{6}{|l|}{ Speak English (ref: very well) } \\
\hline Well, not well, not at all & $1.2(0.4-3.5)$ & $1.1(0.6-2.2)$ & $0.9(0.4-1.7)$ & $1.6(0.8-3.2)$ & $2.2(0.9-5.2)$ \\
\hline \multicolumn{6}{|l|}{ Health insurance (ref: yes) } \\
\hline No & $0.5(0.05-4.3)$ & $1.1(0.3-4.6)$ & $0.8(0.2-4.0)$ & $0.7(0.2-3.0)$ & $0.7(0.02-22.2)$ \\
\hline \multicolumn{6}{|l|}{ Regular provider (ref: yes) } \\
\hline No & $0.6(0.4-1.2)$ & $0.7(0.5-1.1)$ & $0.7(0.5-1.0)$ & $1.0(0.7-1.5)$ & $0.9(0.5-1.7)$ \\
\hline \multicolumn{6}{|l|}{$\begin{array}{l}\text { General health (ref: excellent/ } \\
\text { good) }\end{array}$} \\
\hline Fair/poor & $0.9(0.5-1.7)$ & $1.5(0.8-2.7)$ & $1.3(0.9-2.0)$ & $1.2(0.7-2.1)$ & $1.7(0.9-3.2)$ \\
\hline \multicolumn{6}{|l|}{ Census region (ref: Northeast) } \\
\hline Midwest & $1.9(0.9-3.5)$ & $1.0(0.6-1.9)$ & $1.6(0.9-2.6)$ & $0.9(0.5-1.9)$ & $1.3(0.6-3.0)$ \\
\hline South & $1.5(0.9-2.6)$ & $0.9(0.6-1.5)$ & $1.8(1.0-3.1)$ & $1.3(0.8-2.1)$ & $1.3(0.7-2.7)$ \\
\hline West & $1.8(0.9-3.4)$ & $1.5(0.9-2.5)$ & $2.4(1.4-4.2)$ & $1.1(0.7-1.9)$ & $1.9(0.9-3.9)$ \\
\hline \multicolumn{6}{|l|}{$\begin{array}{l}\text { Rural/ Urban designation (ref: } \\
\text { metro) }\end{array}$} \\
\hline Urban & $1.6(0.9-3.0)$ & $0.9(0.5-1.7)$ & $1.1(0.7-2.0)$ & $1.7(0.9-2.8)$ & $1.1(0.4-2.8)$ \\
\hline Rural & $2.0(0.3-10.9)$ & $1.2(0.2-7.7)$ & $2.2(0.6-8.7)$ & $3.9(1.2-12.8)$ & $3.0(0.1-70.1)$ \\
\hline
\end{tabular}

aOR, adjusted odds ratio; CI, confidence interval.

$n=2,151$ reflects those who accessed their own medical records one or more times in the past 12 months.

*Asians, Pacific Islanders, and multiple races.

${ }^{\dagger}$ Question was omitted in $2018 \mathrm{H} 5 \mathrm{C} 2$, so $n=1033$ (those who accessed their own medical records one or more times in the past 12 months based on $\mathrm{H} 5 \mathrm{C} 1$ only).

Bolded cells are statistically meaningful.

Logistic regression analysis modeled the probability of 1 (e.g., patient viewed results, patient messaged healthcare provider).

facilitators of use, and use. Having a regular doctor represents an environment conducive of $\mathrm{PP}$ use where factors such as physician encouragement and endorsement incentivize patients' adoption of PPs. ${ }^{24,37}$ Research should examine the mediating effect of provider encouragement on the relationship between PP access and use and how this may affect the educational disparities and heightened privacy concerns observed. Lack of health insurance was also associated with decreased access to and use of PPs. This is consistent with previous literature that shows that having a regular provider and health insurance status independently affect access to health care. $^{38,39}$

Our findings are consistent with previous studies on PP access and use by educational attainment. . $^{2021,40}$ Aggressive efforts must be directed to increase registration of underserved patients (eg, onsite registration) 
beyond those suggested for the general population (eg, promotional activities). ${ }^{26,41,42}$ Emphasis on PP access must be coupled with efforts to make information understandable to all patients, particularly those less educated who have difficulties comprehending their records. ${ }^{6,43}$ Disparities still exist in Internet access and mobile device ownership, which negatively impacted PP use in our study. ${ }^{44} \mathrm{We}$ argue that federal ${ }^{45}$ and private ${ }^{46}$ programs that provide cellphones and internet access to underserved communities should be advertised and supported, particularly because Internet access and mobile device ownership might offset age and language proficiency-driven disparities in PPs access and use as observed in our study.

We did not identify differences in PP access and use by race and ethnicity. ${ }^{20,21,40}$ It might be that the variance in $\mathrm{PP}$ access and use was explained by more dominant sociodemographic characteristics (eg, educational attainment) in our study. In a systematic review of facilitators of PP use, racial and ethnic disparities were found in only 6 of 16 studies. ${ }^{37}$ These findings imply that PPs use is not limited by race/ ethnicity but driven by other modifiable factors such as educational attainment and having insurance and a primary care clinician. Studies should examine whether there was an improvement over time in providing access to minorities and the conditions under which minorities are likely to access and use PPs.

Findings on language proficiency underline the need for health literate systems where PPs should accommodate persons with limited literacy and potentially other languages for limited English-proficient patients. ${ }^{47}$ Patients with limited English proficiency may be more likely to be seen in safety-net community clinics that have not fully activated their portals. The responsibility of using PPs fell predominantly on women. This gender difference is consistent with literature showing that women are the main health decision makers for their families. ${ }^{19,48}$ Less use of PPs reported by single and separated/widowed individuals is another manifestation of the effects of social relationships on health. ${ }^{49}$

Consistent with previous studies, ${ }^{18,19,40}$ viewing laboratory results, messaging health care providers, completing forms, making appointments, and refilling medications were the top used functions, which mapped onto the top known functions. Indeed, a study of Veterans Affairs' MyHealtheVet showed that the main reason for nonuse was lack of awareness $(61.3 \%) .{ }^{18}$ Efforts to increase awareness of PPs functionalities are a necessary precursor to use, particularly because certain function are linked to positive outcomes (eg, refill medication, medication adherence). ${ }^{50,51}$ There are lessons to be learned from the high PPs function use in the West Census region. For example, California's healthy PPs adoption rate may be attributable to state investments especially in rural areas. ${ }^{52}$

Lack of confidence in security of electronic records and the less frequent use of some PP functions (eg, monitor health) highlight the necessity of examining PP utility to patients in enhancing communication with clinicians and promoting trust, managing chronic disease-related decisions, and facilitating lifestyle behavioral change among patients with the highest needs. ${ }^{2}$ Research should gauge patients' preferences for procedural factors in using $\mathrm{PPs}^{53,54}$ their perceptions of PP usability, and track their actual PPs use online by socioeconomic status, race/ethnicity, and health literacy. ${ }^{55,56}$

\section{Limitations}

Limitations include the absence of factors that were associated with patients' access and use of PPs in the literature (eg, health literacy). ${ }^{21}$ Some associations could be attributed to confounders: for example, the association between having a regular provider and PP access and use could be attributed to patients' underlying chronic conditions. ${ }^{41}$ Beyond patientlevel characteristics, organizational and contextual factors are key determinants in EHRs adoption (eg, practice size and ownership structure, ${ }^{57,58}$ location, ${ }^{14}$ eligibility for HITECH financial incentives ${ }^{59,60}$ ), which dictate the PP functionalities available to patients. For example, one study showed that private for-profit hospitals (vs private non-profit) were more likely to adopt basic EHRs, which involve a limited set of functionalities implemented in a limited number of clinical units, whereas large hospitals with $\geq 400$ beds (vs with $<100$ beds) were more likely to adopt comprehensive EHRs, which involve expanded functionalities implemented in most clinical units. ${ }^{36}$ Thus, place-based analyses and data linkages to contextualize patients' PP access and use are warranted.

\section{Conclusion}

Using a nationally representative sample of US patients, we identified disparities in PP access and use, driven primarily by patients' educational attainment and whether they have a regular doctor, but not by race and ethnicity. EHRs represent a natural 
migration to electronic platforms in health care, stimulated by federal policies and incentive programs. Despite the mantra that PPs facilitate access to and provision of quality care, actual use of PPs remains low and concerns about data security persist. A wide adoption of PPs rests on patient awareness; perceived utility, usability, and quality; and demand. ${ }^{24}$ Critical to this goal is closing the disparity gap in PPs access and use, especially among individuals of low socioeconomic status, particularly through policy initiatives. Current EHRs are far from being patient centered, but until then, PPs should at least be accessible to all, especially those most in need. ${ }^{43,61}$

\section{Data Availability}

The dataset analyzed during the current study is publicly available from Health Information National Trends Survey:https://hints.cancer.gov/default.aspx.

To see this article online, please go to: bttp://jabfm.org/content/ 33/6/953.full.

\section{References}

1. Office of the National Coordinator for Health Information Technology. Federal health IT strategic plan: 2015-2020. Available from: https://dashboard. healthit.gov/strategic-plan/federal-health-it-strategicplan-2015-2020.php. Accessed October 15, 2018.

2. Detmer D, Bloomrosen M, Raymond B, Tang P. Integrated personal health records: transformative tools for consumer-centric care. BMC Med Inform Decis Mak 2008;8:45.

3. Maurer M, Dardess P, Carman KL, Frazier K, Smeeding L. Guide to patient and family engagement: environmental scan report. Rockville, MD; 2012.

4. Roehrs A, da Costa CA, da Rosa Righi R, de Oliveira KSF. Personal health records: a systematic literature review. J Med Internet Res 2017;19:e13.

5. Office of the National Coordinator for Health Information Technology. What is a patient portal? Available from: https://www.healthit.gov/faq/whatpatient-portal. Accessed June 2, 2018.

6. Ross SE, Lin CT. The effects of promoting patient access to medical records: a review. J Am Med Inform Assoc 2003;10:129-38.

7. Ammenwerth E, Schnell-Inderst P, Hoerbst A. The impact of electronic patient portals on patient care: a systematic review of controlled trials. J Med Internet Res 2012;14:e162.

8. Kaelber DC, Jha AK, Johnston D, Middleton B, Bates DW. A research agenda for personal health records (PHRs). J Am Med Inform Assoc 2008;15: 729-36.

9. 111th Congress. American recovery and reinvestment act. In. Pub.L 111-5. 2009.
10. 111th Congress. Health information technology for economic and clinical health. In. TITLE XIII 2009.

11. 104th Congress. Health Insurance Portability and Accountability Act. In. Public Law 1996;104-191.

12. Committee on Quality of Health Care in America, Institute of Medicine Staff. Crossing the quality chasm: a new health system for the 21 st century. Washington, DC: National Academies Press; 2001.

13. Chaudhry B, Wang J, Wu S, et al. Systematic review: impact of health information technology on quality, efficiency, and costs of medical care. Ann Intern Med 2006;144:742-52.

14. Henry J, Pylypchuk Y, Searcy T, Patel V. Adoption of electronic health record systems among US nonfederal acute care hospitals:2008-2015. ONC Data Brief 35. 2016.

15. Blumenthal D, Tavenner M. The "meaningful use" regulation for electronic health records. N Engl J Med 2010;363:501-4.

16. Centers for Medicare and Medicaid Services. Medicare and Medicaid programs; Electronic health record incentive program-Stage 2. Federal Register. 2012. Available from: https://www.federalregister.gov/ documents/2012/09/04/2012-21050/medicare-andmedicaid-programs-electronic-health-record-incentiveprogram-stage-2. Accessed June 2, 2018.

17. Westin A, Lemieux J, Subias S. Americans overwhelmingly believe electronic personal health records could improve their health. New York, NY: Markle Foundation; 2008.

18. Turvey C, Klein D, Fix G, et al. Blue Button use by patients to access and share health record information using the Department of Veterans Affairs' online patient portal. J Am Med Inform Assoc 2014;21:657-63.

19. Jones JB, Weiner JP, Shah NR, Stewart WF. The wired patient: patterns of electronic patient portal use among patients with cardiac disease or diabetes. J Med Internet Res 2015;17:e42.

20. Ancker JS, Barrón Y, Rockoff ML, et al. Use of an electronic patient portal among disadvantaged populations. J Gen Intern Med 2011;26:1117-23.

21. Sarkar U, Karter AJ, Liu JY, et al. The literacy divide: Health literacy and the use of an internetbased patient portal in an integrated health systemResults from the Diabetes Study of Northern California (DISTANCE). J Health Communicat 2010;15:183-96.

22. Smith SG, O'conor R, Aitken W, Curtis LM, Wolf MS, Goel MS. Disparities in registration and use of an online patient portal among older adults: findings from the LitCog cohort. J Am Med Inform Assoc 2015;22:888-95.

23. Anthony DL, Campos-Castillo C, Lim PS. Who isn't using patient portals and why? Evidence and implications from a national sample of US adults. Health Aff (Millwood) 2018;37:1948-54. 
24. Irizarry T, Dabbs AD, Curran CR. Patient portals and patient engagement: a state of the science review. J Med Internet Res 2015;17:e148.

25. Lin SC, Lyles CR, Sarkar U, Adler-Milstein J. Are patients electronically accessing their medical records? Evidence from national hospital data. Health Aff (Millwood) 2019;38:1850-7.

26. Tieu L, Sarkar U, Schillinger D, et al. Barriers and facilitators to online portal use among patients and caregivers in a safety net health care system: a qualitative study. J Med Internet Res 2015;17:e275.

27. Mishuris RG, Stewart M, Fix GM, et al. Barriers to patient portal access among veterans receiving home-based primary care: a qualitative study. Health Expect 2015;18:2296-305.

28. Pérez-Stable EJ, El-Toukhy S. Communicating with diverse patients: how patient and clinician factors affect disparities. Patient Educ Couns 2018;101:2186-94.

29. Little RJ. A test of missing completely at random for multivariate data with missing values. J Am Statistic Assoc 1988;83:1198-202.

30. Mukhopadhyay PK. Paper SAS3520-2016. Survey data imputation with PROC SURVEYIMPUTE. 2016. Available from: https://support.sas.com/ resources/papers/proceedings16/SAS3520-2016. pdf. Accessed October 19, 2018.

31. Ettner SL. The timing of preventive services for women and children: the effect of having a usual source of care. Am J Public Health 1996;86:1748-54.

32. Fung CS, Wong CK, Fong DY, Lee A, Lam CL. Having a family doctor was associated with lower utilization of hospital-based health services. BMC Health Serv Res 2015;15:42.

33. Lambrew JM, Defriese GH, Carey TS, Ricketts TC, Biddle AK. The effects of having a regular doctor on access to primary care. Med Care 1996;34:138-51.

34. Petersen LA, Burstin HR, O’Neil AC, Orav EJ, Brennan TA. Nonurgent emergency department visits: The effect of having a regular doctor. Med Care 1998;36:1249-55.

35. Centers for Medicare and Medicaid Services. Promoting interoperability programs. Available from: https://www.cms.gov/Regulations-andGuidance/Legislation/EHRIncentivePrograms/ index. Accessed May 30, 2020.

36. Adler-Milstein J, Holmgren AJ, Kralovec P, Worzala C, Searcy T, Patel V. Electronic health record adoption in US hospitals: the emergence of a digital "advanced use" divide. J Am Med Inform Assoc 2017;24:1142-8.

37. Powell KR. Patient-perceived facilitators of and barriers to electronic portal use: a systematic review. Comput Inform Nurs 2017;35:565-73.

38. Sox CM, Swartz K, Burstin HR, Brennan TA. Insurance or a regular physician: Which is the most powerful predictor of health care? Am J Public Health 1998;88:364-70.
39. Freeman JD, Kadiyala S, Bell JF, Martin DP. The causal effect of health insurance on utilization and outcomes in adults: a systematic review of US studies. Med Care 2008;46:1023-32.

40. Sarkar U, Karter AJ, Liu JY, et al. Social disparities in internet patient portal use in diabetes: evidence that the digital divide extends beyond access. J Am Med Inform Assoc 2011;18:318-21.

41. Yamin CK, Emani S, Williams DH, et al. The digital divide in adoption and use of a personal health record. Arch Intern Med 2011;171:568-74.

42. North F, Hanna BK, Crane SJ, Smith SA, Tulledge-Scheitel SM, Stroebel RJ. Patient portal doldrums: does an exam room promotional video during an office visit increase patient portal registrations and portal use? J Am Med Inform Assoc 2011;18:i24-i27.

43. Krist AH, Woolf SH. A vision for patient-centered health information systems. JAMA 2011;305:300-1.

44. Mahmood A, Mosalpuria K, Wyant DK, Bhuyan SS. Association between having a regular health provider and access to services linked to electronic health records. Hosp Top 2019;97:1-10.

45. Federal Communications Commission. Lifeline program for low-income consumers. Available from: https://www.fcc.gov/general/lifeline-programlow-income-consumers. Accessed Feb. 4, 2019.

46. Mobile for All. https://mobileforall.org/. Accessed Feb. 4, 2019.

47. Gibbons MC, Fleisher L, Slamon RE, Bass S, Kandadai V, Beck JR. Exploring the potential of Web 2.0 to address health disparities. J Health Commun 2011;16:77-89.

48. Matoff-Stepp S, Applebaum B, Pooler J, Kavanagh E. Women as health care decision-makers: implications for health care coverage in the United States. J Health Care Poor Underserved 2014;25:1507-13.

49. Umberson D, Karas Montez J. Social relationships and health: a flashpoint for health policy. J Health Soc Behav 2010;51:S54-S66.

50. Sarkar U, Lyles CR, Parker MM, et al. Use of the refill function through an online patient portal is associated with improved adherence to statins in an integrated health system. Med Care 2014;52:194-201.

51. Lin CT, Wittevrongel L, Moore L, Beaty BL, Ross SE. An Internet-based patient-provider communication system: randomized controlled trial. J Med Internet Res 2005;7:e47.

52. Kim KK, Rudin RS, Wilson MD. Health information technology adoption in California community health centers. Am J Manag Care 2015;21:e677-e683.

53. Henshaw D, Okawa G, Ching K, Garrido T, Qian $\mathrm{H}$, Tsai J. Access to radiology reports via an online patient portal: experiences of referring physicians and patients. J Am Coll Radiol 2015;12:582-6. e581.

54. Johnson AJ, Easterling D, Nelson R, Chen MY, Frankel RM. Access to radiologic reports via a 
patient portal: clinical simulations to investigate patient preferences. J Am Coll Radiol 2012;9: 256-63.

55. Czaja SJ, Zarcadoolas C, Vaughon WL, Lee CC, Rockoff ML, Levy J. The usability of electronic personal health record systems for an underserved adult population. Hum Factors 2015;57:491-506.

56. Middleton B, Bloomrosen M, Dente MA, et al. Enhancing patient safety and quality of care by improving the usability of electronic health record systems: recommendations from AMIA. J Am Med Inform Assoc 2013;20:e2-e8.

57. Furukawa MF, King J, Patel V, Hsiao CJ, AdlerMilstein J, Jha AK. Despite substantial progress in EHR adoption, health information exchange and patient engagement remain low in office settings. Health Aff (Millwood) 2014;33:1672-9.
58. Rao SR, DesRoches CM, Donelan K, Campbell EG, Miralles PD, Jha AK. Electronic health records in small physician practices: availability, use, and perceived benefits. J Am Med Inform Assoc 2011; 18:271-5.

59. Adler-Milstein J, Jha AK. HITECH Act drove large gains in hospital electronic health record adoption. Health Aff (Millwood) 2017;36:1416-22.

60. Centers for Medicare and Medicaid Services. Medicare and Medicaid Promoting Interoperability Program Basics. Modified July 20, 2020. Available from: https://www.cms.gov/Regulations-and-Guidance/ Legislation/EHRIncentivePrograms/Basics.html. Accessed Jan. 13, 2019.

61. Fiscella K, Shin P. The inverse care law: Implications for healthcare of vulnerable populations. J Ambul Care Manage 2005;28:304-12. 
Appendix Table 1: Multivariate Logistic Regression Models of Associations between Patient Characteristics, Internet Access, and Electronic Device Ownership, and Use of Personal and Family Patient Portals in the 20172018 Health Information National Trends Survey 5, Cycles 1 and 2, US

Access Own Medical Record, aOR $(95 \% \mathrm{CI})$

Access Family Medical Record, aOR $(95 \% \mathrm{CI})$

Gender (ref: men)

Women

$1.5(1.2-1.8)$

$1.6(1.0-2.3)$

Age (ref: 18 to 39 years)

40 to 59 years

$1.1(0.9-1.4)$

$0.9(0.6-1.4)$

$\geq 60$ years

$1.1(0.9-1.5)$

$0.9(0.5-1.6)$

Race/ethnicity (ref: White)

Latino

$0.9(0.7-1.2)$

$1.1(0.7-1.9)$

Black

$0.9(0.7-1.2)$

$0.8(0.4-1.5)$

Other*

$1.2(0.9-1.7)$

$1.2(0.7-2.0)$

Education (ref: college/post grad)

$<$ High school

$0.5(0.3-0.9)$

$0.8(0.3-2.2)$

High school grad

$0.5(0.4-0.7)$

$0.3(0.2-0.6)$

Vocational, some college

$0.6(0.5-0.7)$

$0.5(0.4-0.8)$

Marital status (ref: married, living as married)

Single

$0.7(0.5-0.9)$

$0.2(0.1-0.6)$

Separated, widowed

$0.8(0.6-0.9)$

$0.5(0.3-0.9)$

Speak English (ref: very well)

Well, not well, not at all

$0.8(0.6-1.1)$

$1.3(0.6-2.4)$

Health insurance (ref: yes)

No

$0.4(0.2-0.7)$

$0.9(0.3-2.5)$

Regular provider (ref: yes)

No

$0.4(0.3-0.5)$

$0.6(0.4-0.9)$

General health (ref: excellent/good)

Fair/poor

$1.0(0.8-1.3)$

$1.1(0.7-1.8)$

Census region (ref: Northeast)

Midwest

$1.3(0.9-1.8)$

$1.2(0.6-2.2)$

$1.0(0.8-1.4)$

$1.2(0.7-2.1)$

West

$1.2(0.9-1.6)$

$1.4(0.8-2.5)$

Rural/urban designation (ref: metro)

Urban

$0.6(0.4-0.8)$

$0.9(0.5-2.1)$

$0.7(0.3-1.5)$

$0.5(0.01-29.3)$

Dial-up (ref: yes)

No

$1.7(0.7-4.1)$

$1.0(0.2-4.5)$

Not ascertained ${ }^{\dagger}$

$0.6(0.2-1.5)$

$1.0(0.2-4.5)$

Broadband (ref: yes)

No

$0.7(0.6-0.8)$

$0.7(0.5-1.0)$

Cell network (ref: yes)

No

$1.2(1.0-1.5)$

$0.9(0.7-1.4)$

Wi-Fi (ref: yes)

No

$0.7(0.6-0.9)$

$0.8(0.5-1.3)$

Tablet (ref: yes)

No

$0.6(0.5-0.7)$

$0.8(0.5-1.3)$

Smartphone (ref: yes)

No

$0.5(0.4-0.6)$

$0.6(0.3-1.2)$ 
aOR, adjusted odds ratio; CI, confidence interval.

$\mathrm{n}=6789$ for access own medical records and $\mathrm{n}=3285$ for access family medical records.

*Asians, Pacific Islanders, and multiple races.

Among those who responded yes to "Do you ever go online to access the Internet or World Wide Web, or to send and receive email?" any internet use was at $82.0 \%(\mathrm{n}=5280 ; 95 \% \mathrm{CI}, 80.6-83.3)$ with dial-up access at $2.3 \%(\mathrm{n}=140 ; 95 \%$ CI, $1.7-3.0)$, broadband access at 52.5\% $(\mathrm{n}=2749 ; 95 \% \mathrm{CI}, 50.2-54.9)$, cell network at $66.2 \%(\mathrm{n}=3099 ; 95 \% \mathrm{CI}, 64.3-68.1)$, and $\mathrm{Wi}-\mathrm{Fi}$ access at $82.1 \%(\mathrm{n}=4178 ; 95 \%$ CI, 80.5-83.6).

Any electronic device ownership was at $98.0 \%(\mathrm{n}=6656 ; 95 \% \mathrm{CI}, 97.5-98.4)$ with tablet ownership at 59.8\% $(\mathrm{n}=3894 ; 95 \% \mathrm{CI}$, 57.7-61.8), smartphone ownership at 79.5\% $(\mathrm{n}=5008 ; 95 \% \mathrm{CI}, 78.2-80.8)$, and cellphone ownership at $15.5 \%(\mathrm{n}=1317 ; 95 \% \mathrm{CI}$, 14.1-16.8).

"“Not ascertained" ( $\mathrm{n}=750)$ were those who reported no internet access and, thus, were not asked questions about means to access the internet via dial up, broadband, cell network, Wi-Fi.

Table includes odds ratio for "not ascertained dial up" only because SAS calculates the first odds ratio for a group of linearly related outcomes, which is the case for "not ascertained" for dial-up, broadband, cell network, and Wi-Fi.

Bolded cells are statistically meaningful.

Logistic regression analysis modeled the probability of 1 (e.g., patient accessed their own medical records). 